\title{
Estimates of fire emissions from an active deforestation region in the southern Amazon based on satellite data and biogeochemical modelling
}

\author{
G. R. van der Werf ${ }^{1}$, D. C. Morton ${ }^{2}$, R. S. DeFries ${ }^{3}$, L. Giglio ${ }^{4}$, J. T. Randerson ${ }^{5}$, G. J. Collatz ${ }^{6}$, and P. S. Kasibhatla \\ ${ }^{1}$ Faculty of Earth and Life Sciences, VU University, Amsterdam, The Netherlands \\ ${ }^{2}$ Department of Geography, University of Maryland, College Park, MD, USA \\ ${ }^{3}$ Department of Ecology, Evolution, and Environmental Biology, Columbia University, New York, NY, USA \\ ${ }^{4}$ Science Systems and Applications, Inc., Lanham, MD, USA \\ ${ }^{5}$ Department of Earth System Science, University of California, Irvine, CA, USA \\ ${ }^{6}$ NASA Goddard Space Flight Center, Greenbelt, MD, USA \\ ${ }^{7}$ Nicholas School of the Environment, Duke University, Durham, NC, USA
}

Received: 13 August 2008 - Published in Biogeosciences Discuss.: 8 September 2008

Revised: 20 January 2009 - Accepted: 20 January 2009 - Published: 20 February 2009

\begin{abstract}
Tropical deforestation contributes to the build-up of atmospheric carbon dioxide in the atmosphere. Within the deforestation process, fire is frequently used to eliminate biomass in preparation for agricultural use. Quantifying these deforestation-induced fire emissions represents a challenge, and current estimates are only available at coarse spatial resolution with large uncertainty. Here we developed a biogeochemical model using remote sensing observations of plant productivity, fire activity, and deforestation rates to estimate emissions for the Brazilian state of Mato Grosso during 2001-2005. Our model of DEforestation CArbon Fluxes (DECAF) runs at 250-m spatial resolution with a monthly time step to capture spatial and temporal heterogeneity in fire dynamics in our study area within the "arc of deforestation", the southern and eastern fringe of the Amazon tropical forest where agricultural expansion is most concentrated. Fire emissions estimates from our modelling framework were on average $90 \mathrm{Tg} \mathrm{C}$ year $^{-1}$, mostly stemming from fires associated with deforestation (74\%) with smaller contributions from fires from conversions of Cerrado or pastures to cropland (19\%) and pasture fires (7\%). In terms of carbon dynamics, about $80 \%$ of the aboveground living biomass and litter was combusted when forests were converted to pasture, and $89 \%$ when converted to cropland because of the highly mechanized nature of the deforestation process in Mato Grosso. The trajectory of land use change from for-
\end{abstract}

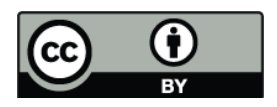

Correspondence to: G. R. van der Werf (guido.van.der.werf@falw.vu.nl) est to other land uses often takes more than one year, and part of the biomass that was not burned in the dry season following deforestation burned in consecutive years. This led to a partial decoupling of annual deforestation rates and fire emissions, and lowered interannual variability in fire emissions. Interannual variability in the region was somewhat dampened as well because annual emissions from fires following deforestation and from maintenance fires did not covary, although the effect was small due to the minor contribution of maintenance fires. Our results demonstrate how the DECAF model can be used to model deforestation fire emissions at relatively high spatial and temporal resolutions. Detailed model output is suitable for policy applications concerned with annual emissions estimates distributed among post-clearing land uses and science applications in combination with atmospheric emissions modelling to provide constrained global deforestation fire emissions estimates. DECAF currently estimates emissions from fire; future efforts can incorporate other aspects of net carbon emissions from deforestation including soil respiration and regrowth.

\section{Introduction}

Tropical deforestation and fire are fundamentally linked because fire is the dominant means to eliminate forest biomass so land can be made suitable for agriculture or grazing. Following deforestation, fires are often used to prevent trees from invading pastures, for nutrient recycling, and to remove crop residues. These fires are collectively referred to

Published by Copernicus Publications on behalf of the European Geosciences Union. 


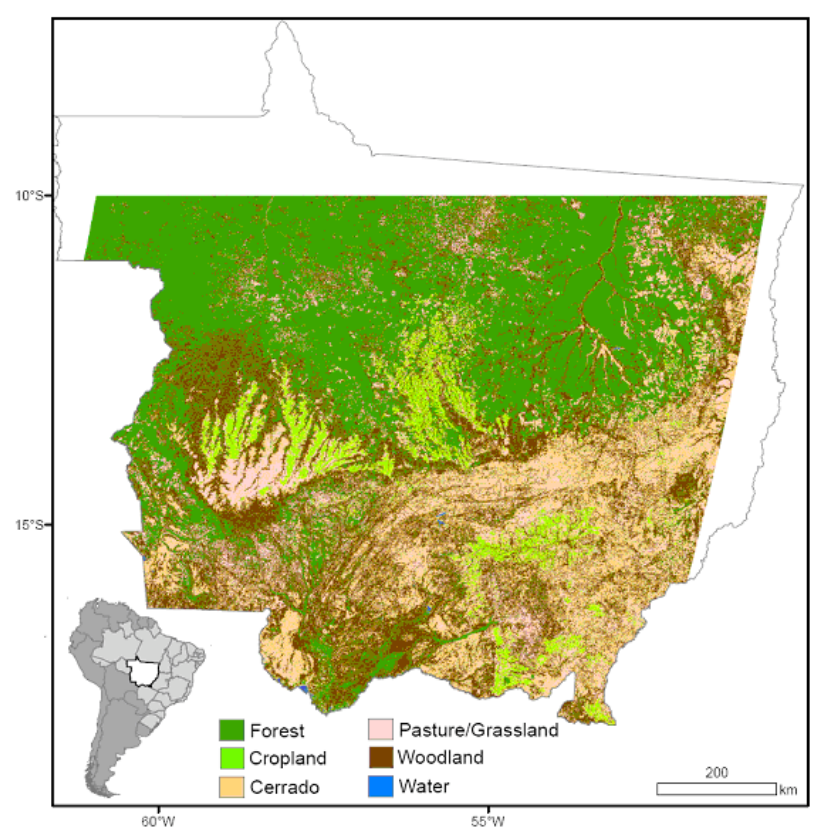

Fig. 1. Land cover in 2001 for the study area in Mato Grosso state.

as maintenance fires since post-fire land use does not change. With many human-induced fires at the tropical forest frontier detected by satellites each year, human activity dwarfs the importance of naturally occurring tropical forest fires started by lightning during extreme drought periods.

Estimates of the total tropical deforestation $\mathrm{CO}_{2}$ source (from both fires and post-fire respiration) are highly uncertain and estimates for the 1990s vary between 0.9 and $2.2 \mathrm{Pg}$ C year ${ }^{-1}$ (DeFries et al., 2002; Houghton, 2003a; Achard et al., 2004). Reducing this large uncertainty is necessary for a number of reasons, including a better understanding of sink strengths in tropical forests (Stephens et al., 2007) and estimating the effectiveness of programs aimed at slowing deforestation to stabilize atmospheric $\mathrm{CO}_{2}$ levels (Santilli et al., 2005; Gullison et al., 2007).

Traditional estimates of the total tropical deforestation flux are based on national statistics on deforestation area or remotely sensed deforestation rates in combination with bookkeeping methods to estimate carbon losses. This bookkeeping method uses response curves that represent the changes in biomass and soil carbon for different land management and land use types to estimate carbon losses from deforestation on annual to decadal time steps (Houghton and Hackler, 1999). The large range in deforestation carbon loss estimates may be partly due to different processes that are accounted for in the various studies (Houghton, 2003b; House et al., 2003) and to the difference in deforestation rates itself, with satellite-based estimates being in general lower than those based on national statistics (DeFries et al., 2002; Houghton et al., 2003b; Grainger, 2008).
Traditional methods lack the ability to provide spatially resolved emissions on a relatively high temporal resolution (e.g., monthly) that could be more readily combined with new top-down (inverse) modeling approaches to estimate emissions. Inverse modelling is based onatmospheric transport and chemistry modelling in combination with measurements of $\mathrm{CO}_{2}$ (e.g., Peters et al., 2007) or carbon monoxide (CO) when focusing on the fraction of emissions that occurs via fire (e.g., Arellano et al., 2006). Apparent inconsistencies between these different approaches may actually be useful to determine different processes. For example, since $\mathrm{CO}_{2}$ inversions measure the full carbon balance of a region including carbon uptake due to forest regrowth, $\mathrm{CO}_{2}$ fertilization, and nitrogen deposition in intact forest, they generally indicate a smaller source from deforestation regions than inventory methods (Ito et al., 2008). The difference between both methods can be used to determine the carbon sink of the region (House et al., 2003). In addition, CO inversions focusing on fires combined with inventory methods may allow for an assessment of committed fluxes.

Our main objective was to build a framework that could provide monthly and annual fire estimates based on medium to high-resolution satellite data. Within this framework we used new information regarding the timing and frequency of fire use for deforestation and the influence of post-clearing land use on combustion completeness. Our model of DEforestation CArbon Fluxes (DECAF) can be used to provide detailed information of fire emissions from multiple land cover conversions (e.g., forest to pasture, forest to cropland, Cerrado savanna-woodland to cropland, etc.). Current fire emissions modelling with atmospheric data (top-down methods) lack a-priori information of the type generated by DECAF, for example for separating deforestation from maintenance fires, limiting their ability to further constrain deforestation fire emissions estimates.

To build and test our framework, we have initially focused on the Brazilian state of Mato Grosso (MT) in the southern Amazon. MT includes Amazon forest in the northern half of the state and Cerrado savanna-woodland land cover types in the southern portion of the state (Fig. 1). Reasons to choose this region include i) Mato Grosso has the highest rates of deforestation and cropland expansion in the Amazon since 2000 (Morton et al., 2006; INPE, 2007), ii) typical clearing sizes occur over much larger areas than the spatial resolution of our main input datasets, iii) a relatively long dry season with low cloud cover facilitates routine use of satellite remote sensing in the visible and near-infrared, and iv) we acquired ground based knowledge regarding deforestation activity and fire use during a series of field campaigns between 2001 and 2006.

In DECAF satellite derived information on area deforested, area burned, and post-fire land use is embedded in a biogeochemical model driven by satellite-derived vegetation characteristics to estimate biomass density at a $250-\mathrm{m}$ spatial resolution. We found that fire emissions for MT for 
2001-2005 were on average $90 \mathrm{Tg} \mathrm{C}$ year $^{-1}$, mostly stemming from deforestation (74\%) and secondary conversions (19\%) rather than from pasture maintenance fires (7\%). Due to the highly mechanized nature of conversion here (Fig. 2), the majority of the aboveground biomass and litter was combusted within the first three years following deforestation ( $80 \%$ when forest was converted to pasture, and $89 \%$ when forest was converted to cropland). This indicates that focusing on fire emissions may provide a new approach for estimating deforestation emissions, especially since fire emissions estimates can be constrained using top-down information.

Our initial effort focused on fire emissions and did not give detailed information about soil carbon losses or carbon uptake following abandonment, although the latter may be partly captured by our use of satellite-derived vegetation greenness. Initial results showed that soil carbon losses could be as large as fire emissions in the extreme case that all soil carbon respired over time, highlighting the need to further constrain this highly uncertain but potentially important source of $\mathrm{CO}_{2}$ emissions associated with deforestation. Both regrowth and a better representation of soil carbon dynamics will be implemented in future versions of DECAF, in combination with expanding our study area to the pan-tropics.

\section{Methods and datasets}

\subsection{Introduction}

Fire emissions are usually calculated as the product of burned area, fuel load, and the fraction of the fuel load that is actually combusted (combustion completeness) and then aggregated over time and space of interest (Seiler and Crutzen, 1980). Here we estimated these three parameters based on satellite data and a simplified biogeochemical model. Because of the relative high spatial resolution (250-m) of our modelling setup, we used a binary approach for burned and cleared area where each grid cell either completely burned or not. This allowed for a more detailed description of the other fire parameters, such as fuel load and combustion completeness, both of which can be highly variable in deforestation regions.

Our satellite-driven model accounted for fire-related emissions from land cover change and land management in the Brazilian state of Mato Grosso covered by MODIS tile h12v10 (Fig. 1). This DEforestation Carbon Fluxes (DECAF) model is a simplified version of the Carnegie Ames Stanford Approach (CASA) biogeochemical model (Potter et al., 1993). DECAF was driven by several satellite derived input datasets to estimate biomass, which was then used in combination with satellite-based burned and cleared area to estimate fire emissions. Below we describe which modifications we made to CASA to develop DECAF (2.2) and the various input datasets that were constructed to estimate monthly
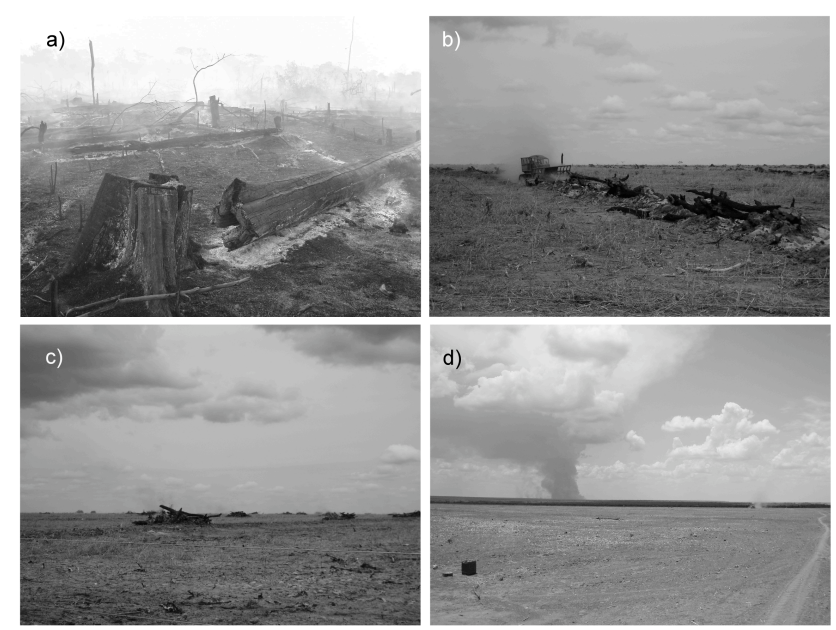

Fig. 2. Mechanized conversion sequence from tropical forest to cropland typical within the study area; (a) deforested area after first fire, (b) remaining woody material mechanically (see bulldozer) piled into "wind rows" and ignited, (c) remaining woody material in small piles further ignited, (d) end result, bare soil suitable for mechanized agriculture, in this case in the year following deforestation. For all stages, the material may undergo multiple ignitions and the total transition may occur in one single dry season or take multiple years. When the forest is converted to pasture, not all trees have to be cut or burned and typically the stumps and roots are not extracted from the ground. All images taken within the Xingu River basin in Mato Grosso state during September 2006.

fire emissions from various types of land cover changes typical in the study region (2.3). DECAF tracks key elements of the fire dynamics that are not typically included in emissions models including: 1) the contribution from several types of fire activity in the region to overall fire emissions, including forest to pasture conversion, forest to cropland conversion, pasture maintenance fires, etc. 2) the timing and duration of deforestation activities, and 3) conversion-type dependent combustion completeness based on satellite-derived fire activity and post-clearing land use.

\subsection{The DEforestation CArbon Fluxes (DECAF) mod- elling framework}

\subsubsection{Model setup}

DECAF is a simplified version of the CASA biogeochemical model that simulates the terrestrial carbon cycle. Because of the large number of grid cells (for this study 20 million, three orders of magnitude more than a global terrestrial run on the typical $1^{\circ} \times 1^{\circ}$ spatial resolution) and because we plan to expand our study area to the pan-tropics we have simplified the original CASA parameterization to make high resolution modelling feasible. The main simplifications included a reduction in the number of belowground carbon pools (from 5 to 2 ) and the derivation of temperature 


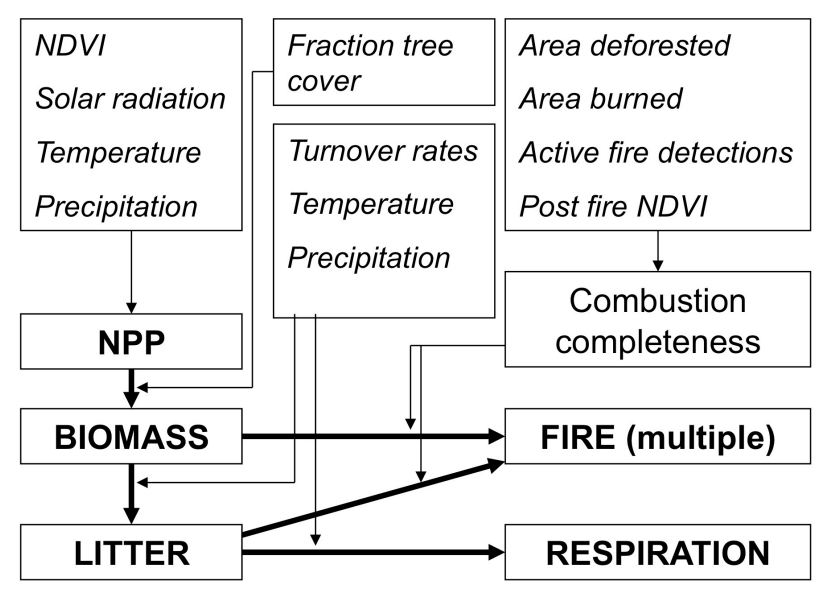

Fig. 3. Flowchart of DECAF with carbon flows and pools in bold and input parameters in italic. Thin arrows indicate which processes are influenced by the input parameters. Note that biomass to litter turnover is independent of temperature or precipitation. NDVI served two main purposes; it was converted to FPAR to calculate NPP, and post fire NDVI phenology was used to assess post fire land use, influencing combustion completeness.

and moisture limitations on heterotrophic respiration using $0.25^{\circ} \times 0.25^{\circ}$ global CASA runs instead of calculating these parameters separately for the $250 \mathrm{~m}$ grid cells. DECAF has three main modules which are further described below: i) the net primary production (NPP) estimation and partitioning to biomass, ii) biomass turnover rates and heterotrophic respiration $\left(R_{h}\right)$, and iii) fire. A schematic representation of DECAF is given in Fig. 3.

\subsubsection{Net primary production}

NPP was calculated for each grid cell and month following Field et al. (1995) based on the fraction absorbed of photosynthetic active radiation (fAPAR) derived from satellitebased normalized difference vegetation index (NDVI), photosynthetically active radiation (PAR), and a light use efficiency factor $(\varepsilon)$ regulated by temperature $(T)$ and moisture $(\theta)$ :

$\mathrm{NPP}=\mathrm{fAPAR} \times \mathrm{PAR} \times \varepsilon_{T, \theta}$

We derived NDVI from the MODIS/Terra Vegetation Indices (MOD13Q1, version 4) at 16-day temporal resolution and $250 \mathrm{~m}$ spatial resolution (Huete et al., 2002), see below. NDVI was converted to fAPAR to provide a full range of possible fAPAR values following techniques developed by Los et al. (2000) and PAR was taken from the climatology of Bishop and Rossow (1991). We set $\varepsilon$ to 0.5 based on comparison of modelled and measured NPP (van der Werf et al., 2006) and followed Potter et al. (1993) to calculate the temperature (based on the New et al., 1999 climatology with anomalies from Hansen et al., 1999) and moisture lim-

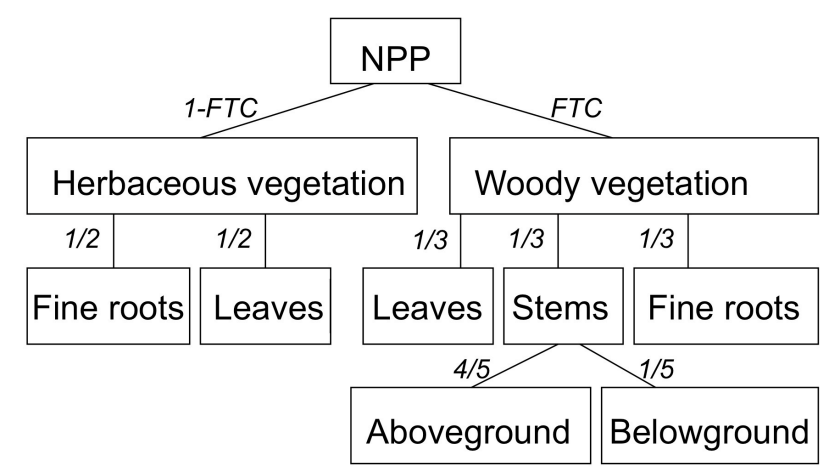

Fig. 4. Net primary production (NPP) allocation model. FTC is fractional tree cover.

itations (based on Tropical Rainfall Measurement Mission data; Iguchi et al., 2000) that regulated $\varepsilon$ when conditions were not optimal for plant growth.

To improve the NDVI quality over our area, we identified cloudy or other low-quality data values using the product's Quality Assurance (QA) layer and replaced those measurements by fitting a local spline function with high-quality data values in each pixel's time series (Morton et al., 2006). Over forested regions, defined as having mean dry-season NDVI $\geq 0.8$, an additional pre-processing step was used to remove remaining cloud contamination and spurious data values. This involved replacing wet-season NDVI values beyond \pm 1 standard deviation of the mean dry-season NDVI values with the dry-season mean NDVI. Monthly NDVI maps at $250 \mathrm{~m}$ resolution were generated from 16-day composites by averaging two composite periods for all months except May, for which a single 16-day composite period beginning on day 129 was used.

\subsubsection{Biomass turnover rates and heterotrophic respiration}

NPP was partitioned among five living biomass pools: woody leaves, fine roots, and stems, and herbaceous leaves and fine roots. The partitioning between woody and herbaceous vegetation was based on MODIS 500 meter fractional tree cover maps (Hansen et al., 2005), and evenly distributed over the living biomass pools within each vegetation type (Fig. 4). We followed the CASA mortality and turnover rates for living biomass (Table 1) but lowered the number of soil carbon and litter pools. Turnover rates were based on regional weighted averages of CASA (Table 1). DECAF has two belowground carbon pools (CASA five); these pools were not subject to fire and mainly influenced soil respiration which was not of direct interest to the present study, but which will be optimized for future model runs where soil respiration is of interest. Litter turnover rates and subsequent heterotrophic respiration were dependent on moisture and temperature; these scalars were imported from $0.25^{\circ} \times 0.25^{\circ}$ CASA runs to save processing time and because the spatial 
Table 1. Carbon pools, their equivalent names in CASA, and turnover rates in DECAF. Note that effective turnover rates for litter pools may be slower when temperature and/or moisture is limiting. DECAF has two surface and soil carbon pools (fast and slow), for which weighted average values are given below.

\begin{tabular}{llc}
\hline Pool & Equivalent in CASA & Turnover rate (years) \\
\hline Wood & Wood & 40 \\
Leaves (woody) & Leaves & 2 \\
Leaves (herbaceous) & Leaves & 0.5 \\
Fine roots (woody) & Fine roots & 1 \\
Fine roots (herbaceous) & Fine roots & 1 \\
Coarse woody debris & Coarse woody debris & 4 \\
Surface litter & Surface structural, metabolic, and microbial & 0.24 \\
Soil carbon & Soil structural, metabolic, microbial, slow, and armored & 5.5 \\
\hline
\end{tabular}

resolution of the required input datasets does not justify higher spatial resolution.

Model spin-up to equilibrium biomass conditions was based on a modified version of the monthly NDVI from 2001. The spin-up took 50 years and involved a shortcut in which the carbon pools with slow turnover rates were filled during the first year based on NPP and turnover times for a single year, lowering the number of years it takes to reach equilibrium. Spin-up NDVI data for pixels that were deforested during 2001 were taken from nearby forested areas. Replacement pixels were selected by finding the closest neighbouring forest pixel; more than $80 \%$ of forest replacement pixels were within $1 \mathrm{~km}$ of the cleared area, and only $2 \%$ of 2001 deforestation pixels were replaced by forest values $>5 \mathrm{~km}$ from the cleared area.

\subsubsection{Fire}

For each month and grid cell, we calculated the fraction of each carbon pool that was combusted. DECAF includes fires for deforestation, conversion of pasture or Cerrado to cropland (secondary transitions), and fires in pasture or Cerrado vegetation that did not result in a change in land cover (maintenance fires). In the case of deforestation, fires could occur in multiple months or even years following the first deforestation event, especially when forest was converted to cropland which requires near-complete removal of biomass (Fig. 2). The methods to retrieve information on these different types of fire are described below, followed by how these different types of fire were included in the model. We derived a low, middle, and high scenario to account for uncertainty in the combustion completeness of the various trajectories (Table 2).

\subsection{DECAF fire input data}

\subsubsection{Deforestation fires and post-clearing land use}

The Brazilian National Institute for Space Research (INPE) has mapped annual deforestation rates since 1988 based on Landsat data under the Monitoramento da Floresta Amazônica Brasileira por Satélite (PRODES) project (Shimabukuro et al., 1998). Since 2000, digital data files for annual deforestation in the Brazilian Amazon maps are produced annually and are have been made available from http://www.obt.inpe.br/prodes. The algorithm used in the PRODES project is based upon changes in a pixel's vegetation fraction, derived from established techniques for subpixel spectral mixture analysis (Câmera et al., 2006). For DECAF, we converted the PRODES data to $250 \mathrm{~m}$ resolution. The effect of resampling on total deforested area was minimal. Annual deforested area in small $(<25 \mathrm{ha})$ polygons was underestimated at model resolution by $6.6 \%$ compared to Landsat-derived area but accounted for only $12 \%$ of all deforestation; deforested area in large ( $>25 \mathrm{ha}$ ) polygons was underestimated by $1.8 \%$ for all conversion during 2001-2005. The relationship between DECAF and PRODES area for individual clearings in 2003 was approximately $1: 1$ (slope $=1.00, R^{2}=0.99$ ), even for clearings $<100$ ha (slope $=0.98, R^{2}=0.92$ ).

Post-clearing land use and the duration of fire activity for deforestation are critical components to determine the transition type and combustion completeness. Based on phenology following deforestation as outlined in Morton et al. (2006), we assigned a post-clearing land use of cropland, pasture, or not in production (NIP) to each deforested area $>25$ ha identified in Landsat-based maps of annual deforestation in our study region (INPE, 2007). The pace of conversion, in years, was defined as the number of years until distinct pasture or cropland phenology appeared. Clearings defined as NIP were not assigned a pace of conversion.

Active fire detections from the Collection 4 MODIS Thermal Anomalies/Fire 5-min swath (Level 2) product at $1 \mathrm{~km}$ 
Table 2. Fire-affected biomass varies among low, middle, and high scenario for each type of post-clearing land use. The fraction of aboveground biomass (tree mortality) and below-ground biomass (root contribution) determine the available biomass for fire emissions. Combustion completeness of the first deforestation fire is also listed for each scenario and land use based on the range of published estimates from Amazonia, although additional burning for deforestation may raise total combustion losses in the first year.

\begin{tabular}{lllll}
\hline \multirow{2}{*}{ Scenario } & \multirow{2}{*}{ Model parameter } & \multicolumn{3}{c}{ Post-clearing land use } \\
& & Cropland & Pasture & Not in production \\
\hline \multirow{3}{*}{ Low } & Tree mortality & 100 & 80 & 50 \\
& Root contribution & 50 & 0 & 0 \\
& Combustion completeness & $0-40 \%$ & $0-40 \%$ & $0 \%$ \\
\hline \multirow{3}{*}{ Middle } & Tree mortality & 100 & 95 & 80 \\
& Root contribution & 80 & 0 & 0 \\
& Combustion completeness & $30-50 \%$ & $20-40 \%$ & $20 \%$ \\
\multirow{3}{*}{ High } & Tree mortality & 100 & 95 & 80 \\
& Root contribution & 90 & 50 & 0 \\
& Combustion completeness & $40-50 \%$ & $40 \%$ & $40 \%$ \\
\hline
\end{tabular}

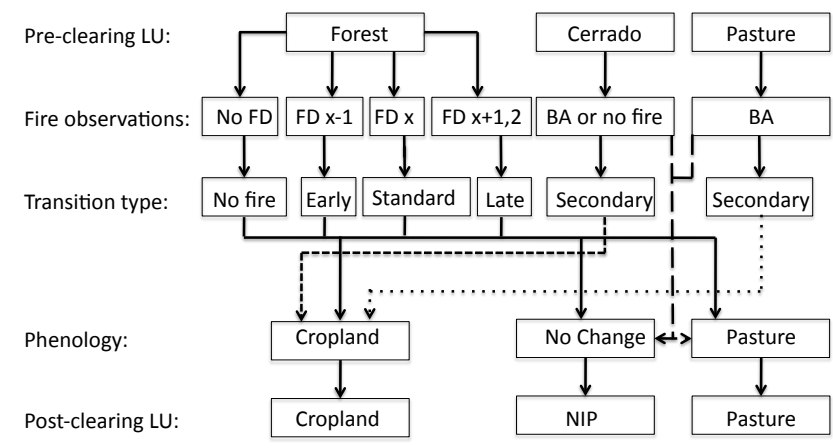

Fig. 5. Land use (LU) change options in DECAF. Pre-clearing LU (see Fig. 1) is derived from Morton et al. (2009) and is consistent with the delineation of forest and non-forest areas in PRODES (INPE, 2007). Fire observations are either MODIS burned area (BA) in pasture or Cerrado or PRODES deforestation areas combined with MODIS active fire detections (FD) in forested regions, where $\mathrm{x}$ denotes the year that PRODES detected deforestation. Fires $\mathrm{x}-1$ describes the condition where fires were detected in the year prior to deforestation mapping, whereas Fires $x+1$ indicates that initial MODIS active fire detections in a deforested area occurred in the year after deforestation was detected. The timing and duration of fire activity and post-clearing LU were used to define the transition type for each deforestation event (see Table 3). Fire-related transitions in Cerrado or pasture land cover types are divided between cropland conversion and maintenance fires in DECAF.

spatial resolution (MOD14/MYD14) (Giglio et al., 2003), summarized in terms of the number of unique days each year on which active fires were detected by the MODIS sensors in the same grid cell (fire days) (Morton et al., 2008), were used to complement the phenology-based classification. Clearings with agreement between the pace of conversion and the dura- tion of high-frequency fire activity, defined as the number of years with 3 or more fire days, were assigned to "standard" 1, 2, or 3-year trajectories (Table 3, Fig. 5).

When the pace of conversion and duration of highfrequency fire activity differed, fire data were used to modify the deforestation trajectory in three ways (Fig. 5). First, due to the difference in timing between deforestation mapping (August) and the end of the burning season in southern Amazonia (October), forest areas that were cleared and burned in September or October may not be mapped until the following year. Deforested areas that burned on at least 1 day (average of $>0.5$ fire days per polygon per year) in the year prior to being mapped were added to the fire transition layer from the previous year (early trajectory). Since combustion completeness of the initial fire in a deforested area can exceed $60 \%$ (Carvalho et al., 2001), capturing the timing of initial fire activity is critical for estimating fire emissions from deforestation. Approximately $19 \%$ of all deforestation during 2001-2005 was burned in the year prior to being mapped by PRODES (Table 3). Second, the duration of high-frequency fire activity was used to extend the conversion pace of some deforested areas. For example, a deforested area in which pasture phenology appeared in the first year following forest clearing but for which high-frequency fire activity lasted two years would be assigned to the "late" trajectory, indicating that some amount of biomass remained to permit multiple fires in the second year (see Table 3). Finally, deforested areas without any corresponding fire activity (average of $<0.3$ fire days per polygon in any year) were assigned to the "no fire" trajectory (Fig. 5). The no-fire trajectory is only used in the low emissions scenario. Deforestation without corresponding fire detections was most common for NIP (19\%) and pasture (9\%) deforestation (Table 3$)$. In summary, combined evidence for the duration of deforestation emissions from MODIS data on post-clearing phenology and fire 
Table 3. Percent of fire-affected woody biomass remaining for each transition type in October of years 1-3 following forest clearing as well as the duration of the transition. Remaining biomass is shown as the middle estimate scenario; low and high emissions scenarios are shown in parentheses for each year. The 10 most important conversion types in terms of area (final column) are in italic.

\begin{tabular}{|c|c|c|c|c|c|c|c|}
\hline Pre-clearing land use & Post-clearing land use & Duration (years) & Transition type & Year 1 & Year 2 & Year 3 & Relative area (\%) \\
\hline Cerrado & Cropland & 1 & Secondary ${ }^{\mathrm{a}}$ & $0(10,0)$ & & & 29.51 \\
\hline Pasture & Cropland & 1 & Secondary ${ }^{\mathrm{a}}$ & $0(10,0)$ & & & 19.46 \\
\hline Forest & Cropland & 1 & No fire ${ }^{b}$ & $0(10,0)$ & & & 0.12 \\
\hline Forest & Cropland & 1 & Early $^{\mathrm{c}}$ & $50(60,30)$ & $0(10,0)$ & & 1.62 \\
\hline Forest & Cropland & 1 & Standard $^{\mathrm{d}}$ & $O(10,0)$ & & & 3.31 \\
\hline Forest & Cropland & 1 & Early and late $\mathrm{e}^{\mathrm{e}}$ & $60(60,50)$ & $10(20,10)$ & $0(10,0)$ & 0.25 \\
\hline Forest & Cropland & 1 & Late $^{\mathrm{f}}$ & $10(20,10)$ & $O(10,0)$ & & 2.71 \\
\hline Forest & Cropland & 2 & No fire ${ }^{b}$ & $30(100,30)$ & $0(-, 0)^{\mathrm{i}}$ & & 0.00 \\
\hline Forest & Cropland & 2 & Early ${ }^{\mathrm{c}}$ & $60(60,60)$ & $30(40,30)$ & $0(10,0)$ & 0.12 \\
\hline Forest & Cropland & 2 & Standard ${ }^{\mathrm{d}}$ & $30(60,30)$ & $0(10,0)$ & & 0.18 \\
\hline Forest & Cropland & 3 & No fire ${ }^{b}$ & $50(100,50)$ & $20(-, 20)^{\mathrm{i}}$ & $0(-, 0)^{\mathrm{i}}$ & 0.02 \\
\hline Forest & Cropland & 3 & Early ${ }^{\mathrm{c}}$ & $60(60,60)$ & $30(40,40)$ & $0(10,0)$ & 0.00 \\
\hline Forest & Cropland & 3 & Standard $^{\mathrm{d}}$ & $50(60,50)$ & $20(30,20)$ & $0(10,0)$ & 0.43 \\
\hline Forest & Pasture & 1 & No fire ${ }^{\mathrm{b}}$ & $30(100,10)$ & & & 2.02 \\
\hline Forest & Pasture & 1 & Early $^{\mathrm{c}}$ & $60(60,60)$ & $30(50,10)$ & & 5.96 \\
\hline Forest & Pasture & 1 & Standard $\mathrm{d}^{\mathrm{d}}$ & $30(50,10)$ & & & 18.07 \\
\hline Forest & Pasture & 1 & Early and late $\mathrm{e}^{\mathrm{e}}$ & $60(70,60)$ & $20(50,10)$ & & 0.08 \\
\hline Forest & Pasture & 1 & Late $^{\mathrm{f}}$ & $40(50,20)$ & $30(40,10)$ & & 1.59 \\
\hline Forest & Pasture & 2 & No fire ${ }^{b}$ & $50(100,40)$ & $30(-, 10)^{i}$ & & 0.34 \\
\hline Forest & Pasture & 2 & Early ${ }^{\mathrm{c}}$ & $60(70,60)$ & $50(60,20)$ & $30(50,10)$ & 0.35 \\
\hline Forest & Pasture & 2 & Standard $^{\mathrm{d}}$ & $50(60,40)$ & $30(50,10)$ & & 1.34 \\
\hline Forest & Pasture & 3 & No fire ${ }^{b}$ & $65(100,50)$ & $45(-, 30)^{\mathrm{i}}$ & $30(-, 10)^{\mathrm{i}}$ & 0.29 \\
\hline Forest & Pasture & 3 & Early & $75(70,60)$ & $50(60,30)$ & $30(50,10)$ & 0.08 \\
\hline Forest & Pasture & 3 & Standard $^{\mathrm{d}}$ & $65(70,50)$ & $45(60,30)$ & $30(50,10)$ & 1.08 \\
\hline Forest & NIPg & 3 & No fire ${ }^{b}$ & $80(100,50)$ & $50(-, 30)^{i}$ & 40 & 1.06 \\
\hline Forest & NIPg & 3 & Early ${ }^{\mathrm{c}}$ & $80(100,60)$ & $50(-, 30)^{\mathrm{i}}$ & 40 & 1.34 \\
\hline Forest & NIPg & 3 & Standard $^{\mathrm{d}}$ & $80(100,50)$ & $50(-, 30)^{\mathrm{i}}$ & 40 & 1.44 \\
\hline Forest & NIPg & 3 & Late $^{\mathrm{f}}$ & $80(100,60)$ & $50(-, 30)^{\mathrm{i}}$ & 40 & 0.44 \\
\hline Forest & Cropland & 1 & Small $^{\mathrm{h}}$ & $0(10,0)$ & & & 1.19 \\
\hline Forest & Pasture & 2 & Small $^{\mathrm{h}}$ & $55(60,10)$ & $30(50,10)$ & & 5.33 \\
\hline
\end{tabular}

a Secondary: The conversion of pasture to cropland is considered a secondary land use following historic conversion of forest or Cerrado to pasture. ${ }^{b}$ No fire: Deforestation events without corresponding MODIS active fire detections in any year (see Morton et al., 2008). ${ }^{c}$ Early: Deforestation events with MODIS active fire detections in the year prior to inclusion in PRODES. ${ }^{\mathrm{d}}$ Standard: Deforested areas in which MODIS fire activity is consistent with phenology-based conversion pace. ${ }^{\mathrm{e}}$ Early and late: Deforestation events with fires in the year prior to deforestation mapping and additional high-frequency MODIS fire detections in the year after the appearance of pasture or cropland phenology. ${ }^{\mathrm{f}}$ Late: Deforestation events with high-frequency fire detections in the year after the appearance of pasture or cropland phenology. $\mathrm{g}$ Not in production: Possibly cleared and then abandoned, these deforested areas do not exhibit post-clearing land use of pasture or cropland. ${ }^{\mathrm{h}}$ Clearings smaller than 25 ha. ${ }^{\mathrm{i}}$ - indicates that there were no additional fires in the low scenario

detections was used to assign a combustion completeness trajectory to individual clearings $>25 \mathrm{ha}$.

Small deforestation areas $(<25 \mathrm{ha}$ ) were divided between cropland and pasture based on their proximity to the cropland land cover class in 2006. Small deforestation events within $500 \mathrm{~m}$ of cropland were considered extensions of existing crop fields, and the remaining areas were assigned pasture land use. A description of how the different land classes were classified is given in Sect. 2.5. Secondary transitions, defined as the conversion of existing pasture to cropland, were identified using the phenology-based classifications in years 4+ after initial forest clearing. Thus, secondary transitions from 2000 deforestation were added into layers for 2003-
2005; secondary transitions from pasture in 2001 deforestation were added into 2004 and 2005, and 2002 deforestation that transitioned from pasture to cropland use in 2005 was added to that layer.

\subsubsection{Cropland expansion}

Two MODIS-based classification approaches were used to identify the conversion of pasture to cropland. In previouslyforested areas ("historic deforestation", INPE, 2007), the classification approach developed by Morton et al. (2006) was used to identify the conversion of pasture to cropland. In the southern half of the state that is dominated by Cerrado 
vegetation, a more detailed classification developed to separate cropland from Cerrado vegetation types was used to identify pasture or Cerrado conversion to cropland in nonforest areas (Morton et al., 2009). Annual expansion of cropland was identified by comparing annual classification results, limiting new expansion to regions larger than two 250$\mathrm{m}$ MODIS pixels ( $\sim 10 \mathrm{ha})$ outside of wetlands and indigenous reserves. For this transition type, we assumed that all grass and woody biomass was burned during the conversion to mechanized crop production (Table 3).

\subsubsection{Management fires in pasture or Cerrado}

Fires for pasture management or in Cerrado savannawoodland vegetation (Fig. 1) that did not result in a conversion to cropland were identified using a $500 \mathrm{~m}$ MODIS burned area product (Giglio et al., 2009). The algorithm used identified persistent change in surface reflectance typical of burned areas. For use in DECAF, the product was resampled to $250 \mathrm{~m}$ resolution and aggregated from daily burning information to a monthly time step.

\subsection{Modelling fire in DECAF}

We developed the deforestation emissions trajectories in Table 3 based on four lines of evidence: 1) field studies described in the literature, 2) satellite-based fire frequency, 3) our field experience, and 4) satellite-derived conversion pace. The range of combustion completeness from field studies for the initial fire in deforested areas in Amazonia is 19.5\% to 61.5\% (Carvalho et al., 2001; Kauffman et al., 1995; Guild et al., 1998; Araujo et al., 1999; Nepstad et al., 2001; Laurance et al., 2004), with the average of published estimates of $40.6 \%$. Morton et al. (2008) used low, average, and high combustion completeness from field studies to estimate the combustion completeness of the multi-year deforestation process in this region using satellite-based fire frequency information. Average fire usage in the conversion of forest to cropland was 3 fire days in the first year, and 5 fire days over the entire deforestation process. Conversion of forest to pasture averaged 1 fire day in the first year and 3 fires during the 1-3 years following deforestation (Morton et al., 2008). Estimated combustion completeness following 1 fire (20-60\%), 3 fires (50-95\%), and 5 fires (70-100\%) formed the initial bounds for our deforestation trajectories in low, middle, and high emissions scenarios (Tables 2 and 3 ).

Combustion completeness estimates derived from fire frequency data are consistent with previous studies and our field knowledge. In order to permit tractor use for crop production, we assumed that no more than $10 \%$ of aboveground biomass and $50 \%$ of root biomass may remain at the end of the fire-related conversion period. Our low emissions scenario for pasture land conservatively assumed that no more than $50 \%$ of initial aboveground forest biomass could remain on site. Remaining biomass following pasture deforestation in middle (30\%) and high (10\%) scenarios is consistent with reports of $25-104 \mathrm{Mg} / \mathrm{ha}$ residual woody debris in Amazon pastures (Kauffman et al., 1998), or approximately 10-33\% of initial forest biomass (Kauffman et al., 1995). For areas that were defined as NIP, we assigned no fire emissions under the low emissions scenario. The low emissions scenario was further constrained using active fire data; only deforestation polygons showing active fire detections were allowed to burn. In each scenario, the conversion pace for each deforestation event was used to distribute the fire activity over 1-3 years. Canopy-tree mortality and the emissions contribution from belowground biomass are not well constrained by field experiments. Table 2 shows the estimated contributions from above and belowground biomass for each emission scenario based on field knowledge of the study region.

Emissions scenarios for the conversion of pasture or Cerrado to cropland were treated similarly to deforestation for cropland, with combustion completeness of any remaining aboveground biomass limited to $90 \%$ in the low emissions scenario. Maintenance fires burned $95 \%$ of all herbaceous biomass and fine litter and 5\% of structural biomass in all scenarios.

\subsection{Land cover}

Field-validated land cover maps were generated using seasonal metrics from time series of NDVI and Enhanced Vegetation Index (EVI) (Morton et al., 2009), and summarized into 6 land cover classes: forest, cropland, Cerrado (woody savanna), pasture/grassland, woodland (Cerradão), and water (see Fig. 1). At an annual time step, land cover maps were updated in DECAF based on fire-related land cover changes that converted forest, pasture, or Cerrado land cover to agricultural classes (cropland or pasture). Land cover information was used to calculate mean NPP and biomass estimates for the different land cover classes for comparison to other reported values, but not used as an input dataset in DECAF as none of the model calculations depend on land cover.

\section{Results}

The results of our modelling approach are described below in three subsections; model results for Net Primary Production (NPP) and biomass (Sect. 3.1), emissions estimates (3.2), and carbon dynamics (3.3).

\subsection{NPP and biomass}

Maps of mean annual NPP and biomass are shown in Figs. 6 and 7. Average forest NPP was $1131 \pm 118(1 \sigma$ range) $\mathrm{g} \mathrm{C} \mathrm{m}^{-2}$ year $^{-1}$ with lower annual NPP for Cerrado, croplands, and pasture mostly due to more seasonality in the NDVI signal compared to forests (Table 4). Higher NPP and more woody biomass with low turnover times resulted in higher biomass loads in forests $(178 \pm 62 \mathrm{Mg}$ dry matter 
Table 4. Average net primary production (NPP, $\mathrm{g} \mathrm{C} \mathrm{m}^{-2}$ year $^{-1}$ ) and aboveground living biomass (AGLB, in $\mathrm{Mg}$ dry matter ha ${ }^{-1}$ assuming a dry matter carbon content of 50\%) for different land cover classes.

\begin{tabular}{lll}
\hline Land cover class & NPP & AGLB \\
\hline Forest & $1131 \pm 118$ & $178 \pm 62$ \\
Cropland & $529 \pm 238$ & $26 \pm 17$ \\
Cerrado & $400 \pm 319$ & $29 \pm 19$ \\
Grassland & $392 \pm 301$ & $22 \pm 17$ \\
Woodland & $482 \pm 458$ & $78 \pm 57$ \\
\hline
\end{tabular}

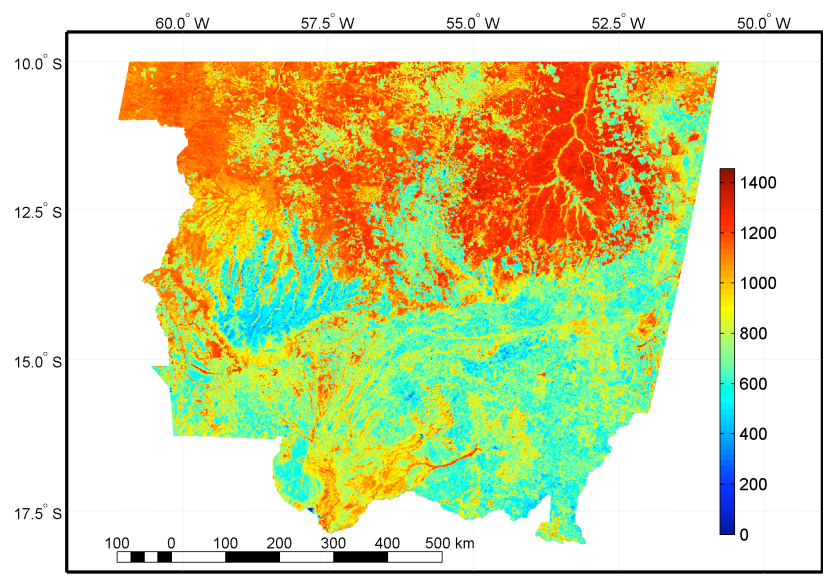

Fig. 6. DECAF estimated net primary production for the study region, averaged over 2001-2005 ( $\mathrm{g} \mathrm{C} \mathrm{m}^{-2}$ year $\left.^{-1}\right)$.

(DM) ha ${ }^{-1}$ ) than in other land cover classes such as woodlands (78 \pm 57 ), Cerrado (29 \pm 19$)$, and croplands without harvest losses (26 \pm 17$)$. DECAF estimates carbon fluxes and stocks in carbon; we assumed a dry matter carbon content of $50 \%$ to convert these numbers to DM.

Average modelled forest aboveground living biomass (AGLB) compared reasonably against other measurements (Fig. 8), with somewhat lower AGLB than plot-based measurements from Imazon ${ }^{1}$ and higher values than those from Saatchi et al. (2007). The latter is also a modelling study and used the Radambrasil forest inventory which took place between 1973 and 1983 in their algorithm. Recent biomass measurements were made in the southeastern edge of the Xingu basin by Balch et al. (2008), our estimates $\left(220 \mathrm{Mg} \mathrm{DM} \mathrm{ha}^{-1}\right)$ were somewhat higher than measured

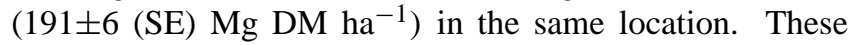
measurements excluded all trees smaller than $10 \mathrm{~cm}$ DBH which may partly explain the difference. This, however, is also the case with other measurements that were in general higher than our estimates. Monteiro et al. (2004), for example, measured higher biomass $\left(326 \mathrm{Mg} \mathrm{DM} \mathrm{ha}^{-1}\right)$ than our

\footnotetext{
${ }^{1}$ http://www.imazon.org.br/home/index.asp?lg=en
}

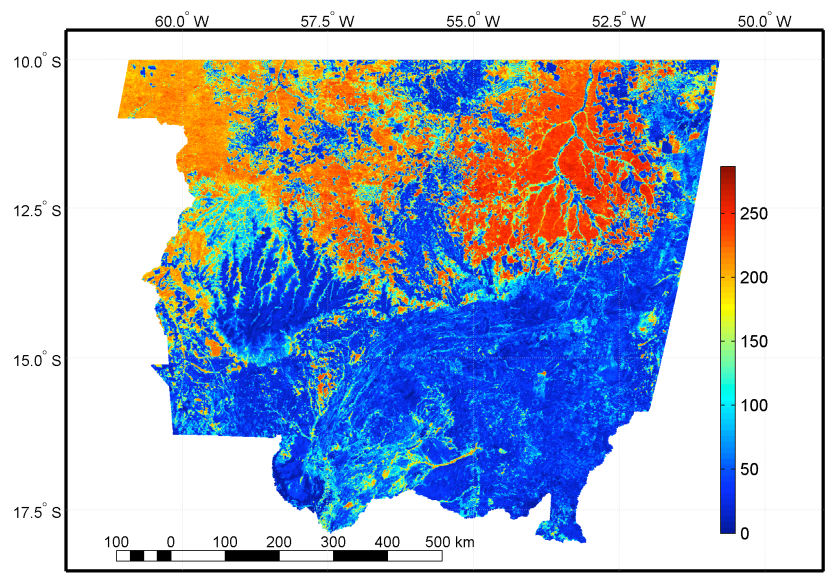

Fig. 7. DECAF estimates of aboveground living biomass for the study region in $\mathrm{Mg}$ dry matter $(\mathrm{DM}) \mathrm{ha}^{-1}$ assuming a DM carbon content of $50 \%$.
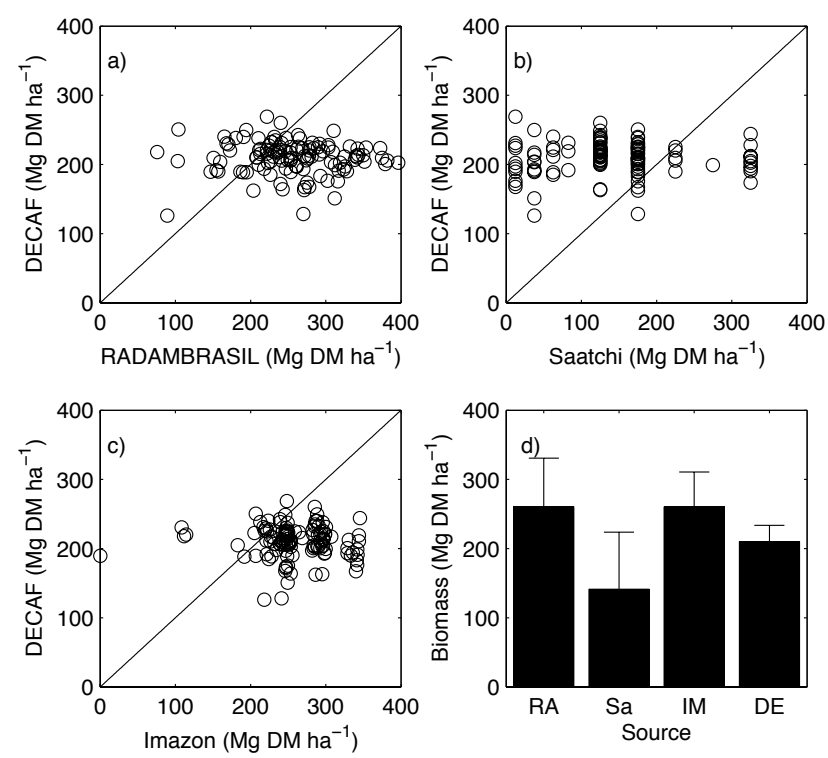

Fig. 8. DECAF (DE) estimated biomass compared in Mg dry matter (DM) ha ${ }^{-1}$ with plot measurements from Radambrasil (RA), remote sensing-based estimates from Saatchi et al. (2007) (Sa) which were also validated using Radambrasil data, and the Imazon (IM) database. All comparisons were based on grid cells in MT where measurements from Radambrasil were made and which were classified as forest.

model $\left(248 \mathrm{Mg} \mathrm{DM} \mathrm{ha}^{-1}\right)$ in the western edge of the Xingu basin. DECAF biomass is spatially more uniform than measurements indicate and cannot reproduce the higher biomass values in the northwestern part of the study area.

\subsection{Emissions estimates}

Emissions over 2001-2005 were on average $90 \mathrm{Tg} \mathrm{C}$ year $^{-1}$ (Table 5). Most of these emissions stem from deforestation 
Table 5. Emission estimates ( $\operatorname{Tg} \mathrm{C}$ year ${ }^{-1}$ ) for different types of fire. Emission estimates are given for the "middle" scenario with estimates based on the low and high scenario in parentheses.

\begin{tabular}{|c|c|c|c|c|c|c|}
\hline \multirow[t]{2}{*}{ Source } & \multicolumn{5}{|c|}{ Year } & \multirow[t]{2}{*}{ Mean } \\
\hline & 2001 & 2002 & 2003 & 2004 & 2005 & \\
\hline Deforestation & $63(39-68)$ & $62(42-69)$ & $71(51-78)$ & $58(41-65)$ & $35(21-41)$ & $58(39-64)$ \\
\hline Deforestation previous years $\mathrm{a}$ & $-^{\mathrm{d}}$ & $9(6-7)$ & $11(9-9)$ & $14(11-13)$ & $13(7-12)$ & $9(7-8)^{\mathrm{e}}$ \\
\hline Maintenance $\mathrm{b}^{\mathrm{b}}$ & 4 & 7 & 5 & 8 & 6 & 6 \\
\hline Other ${ }^{\mathrm{c}}$ & $13(13-13)$ & $14(14-14)$ & $18(18-18)$ & $21(21-22)$ & $18(18-19)$ & $17(17-17)$ \\
\hline Total & $80(55-85)$ & $92(69-98)$ & $105(83-111)$ & $102(81-108)$ & $73(53-78)$ & $90(70-97)^{\mathrm{e}}$ \\
\hline
\end{tabular}

a Emissions stemming from areas deforested in previous years, referred to as "carry-over" emissions in the text. ${ }^{\mathrm{b}}$ Emissions stemming from pasture burning and Cerrado fires with fixed combustion completeness ${ }^{\mathrm{c}}$ Emissions stemming from conversion of Cerrado or pasture to cropland, referred to as secondary transitions in the text. ${ }^{d}$ Not calculated ${ }^{\mathrm{e}}$ Assuming deforestation events prior 2001 did not result in emissions in 2001, both to be conservative and because deforestation rates were low in 2000. If emissions from deforestation previous years in 2001 was taken as the average from 2002-2005 then mean emissions due to deforestation previous years was 12 (8-10) and total emissions would be 93 (70-98) $\mathrm{Tg} \mathrm{C}_{\text {year }}^{-1}$.
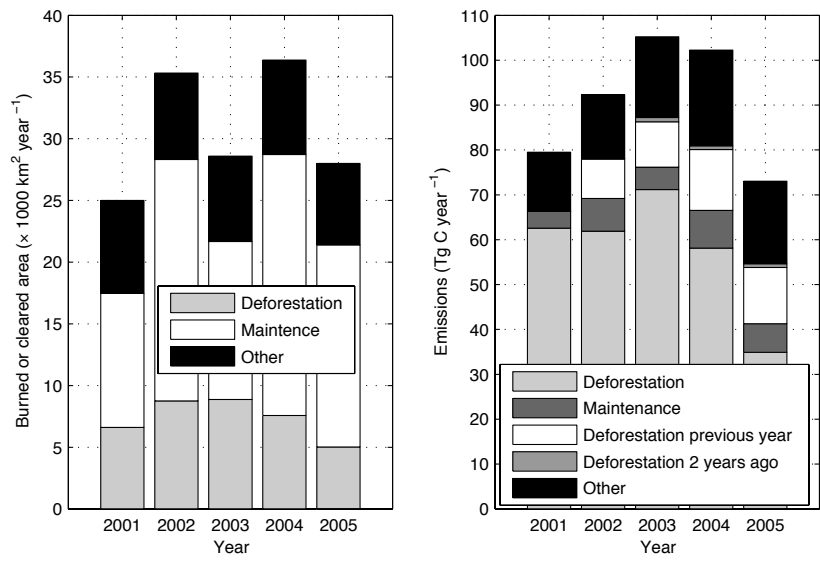

Fig. 9. Annual burned or cleared area (left) and emissions (right) for deforestation and maintenance fires. Maintenance fires include pasture and Cerrado fires. Other is conversion of non-forest to cropland or pasture.

fires in the first dry season following deforestation (64\%) while maintenance fires contributed only $7 \%$ on average. The remainder stems from conversion of pasture or Cerrado to cropland (19\%, "other" in table 3 ) or from deforestation but emitted in the second $(10 \%)$ or third $(1 \%)$ dry season following deforestation, which we will refer to as carry-over emissions. A more detailed discussion on how the various conversion types contribute to overall emissions is given in DeFries et al. (2008).

Interannual variability over our study period was substantial with a minimum during $2005\left(73 \mathrm{Tg} \mathrm{C} \mathrm{year}^{-1}\right)$ and a maximum in 2003 (105 Tg C year ${ }^{-1}$ ), see Fig. 9. Interannual variability in emissions from deforestation and from maintenance fires were not correlated $(p=0.72)$. Interannual variability was somewhat dampened by carry-over; in 2005, for example, deforestation emissions were low but carry-over was above average lowering the decrease in emissions.

The different scenarios (low and high) altered these estimates substantially and highlight the sensitivity of our results to combustion completeness estimates (Table 3). The low combustion completeness assumption reduced average deforestation emissions in the first year by $40 \%$. The increase due to higher combustion completeness values in the high scenario was $16 \%$, and carry-over in the high scenario was lower than in the middle scenario because high combustion completeness in the first year reduced biomass loads that may be burned in subsequent years.

\subsection{Carbon dynamics}

We estimated that for conversions of forest to pasture, on average $80 \%$ of the aboveground living biomass and litter was combusted during the conversion process. For conversions of forest to cropland, this increased to $89 \%$ (Fig. 10). The higher combustion completeness for conversion to cropland is the result of higher mortality rate of aboveground biomass and more frequent fire activity. If we also take soil carbon and belowground biomass into account, $51 \%$ of total available carbon was combusted in conversion to pasture and $64 \%$ when forest was converted to cropland. The difference is larger due to complete bole extraction, which is necessary when forest is converted to cropland but not in conversions to pasture. It should be noted, however, that the soil carbon pools are not tuned specifically to this region so these numbers are uncertain.

$R_{h}$ (heterotrophic respiration) stemmed mostly from ongoing soil respiration during the conversion and from respiration of slash, mostly during the wet season. Total $R_{h}$ over 3 years following deforestation was $36 \%$ and $21 \%$ of fire emissions for conversion to pasture and cropland, respectively. 
Committed emissions (all litter and soil carbon leftover after 3 years) were equal to another $52 \%$ or $32 \%$ of fire emissions. Stated differently, even when forest was converted to pasture and when assuming that all modelled soil carbon will respire over time, the fire flux was still marginally larger than $R_{h}$ (53\% vs. $47 \%$ ). For conversion to cropland and when only considering living biomass (above and belowground) and litter, the partitioning was $79 \%$ vs. $21 \%$ or $65 \%$ vs. $35 \%$ when taking all soil carbon into account.

\section{Discussion}

\subsection{Biomass}

Our aboveground living biomass (AGLB) estimates for the region falls within the range of other estimates, but our model could not reproduce the spatial distribution of AGLB described by previous studies for our study region. Specifically, plot level measurements indicate higher AGLB in the forests in the northwest than in the Xingu River basin in the eastern portion of the study area. We found, however, lower NDVI values here, which translated into lower NPP and lower wood biomass due to the fixed wood turnover rate. In general, higher AGLB loads in the interior of the Amazon may be associated with a shorter dry season (ter Steege et al., 2006). In the future, this gradient can be simulated based on the NPP allocation with more NPP allocated to stems and leaves in high precipitation regions (Litton et al., 2007). Within our study area, however, the gradient was not caused by climatic conditions and could not be reproduced by our relatively simple modelling approach. In the Xingu basin, where most deforestation takes place, however, AGLB estimates were close to measurements or predictions from other studies.

\subsection{Emissions}

Averaged over the study period, our emission estimates were comparable to estimates generated by two alternate approaches (DeFries et al., 2008). Interannual variability in emissions was significant, especially in deforestation and maintenance emissions (coefficient of variation of 0.24 and 0.30). Climate variability over 2001-2005 in MT was small, and each year had three months with rainfall rates below $20 \mathrm{~mm} \mathrm{month}^{-1}$. The year with lowest rainfall rates (when taking each 3 or 4 month window between May and September) was 2005 and the highest precipitation rates occurred in 2001. Over our study period, rainfall rates and deforestation were not related ( $p=0.68$ for 5 month dry season precipitation vs. deforestation rates), possibly due to the low climate variability over our study period or because other factors were more important. Morton et al. (2006), for example, found a good correlation $\left(R^{2}=0.72\right)$ between the price of soy and area deforested to cropland in the same region over 2001-2004, highlighting the important role of socioeconomic drivers. When taking a longer time period into
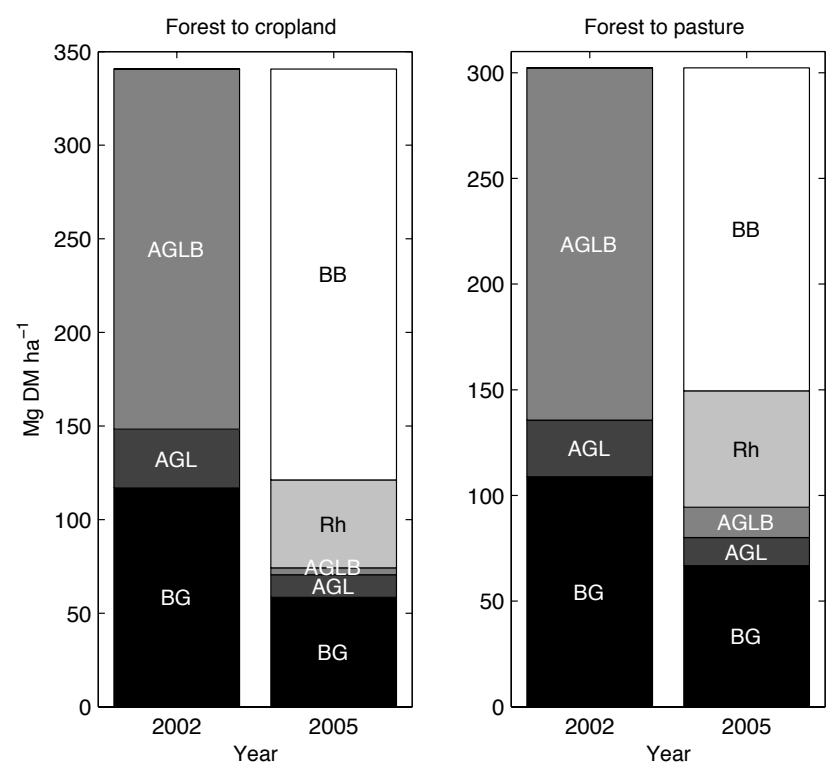

Fig. 10. Fate of carbon in aboveground living biomass (AGLB), aboveground litter (AGL), and belowground biomass and litter (BG) for areas undergoing conversion from forest to cropland (left panel) or to pasture (right panel). Bars on the left represent the biomass and litter present before 2002 conversion, bars on the right represent how much AGLB, AGL, BG remained in 2005, and how much had respired $\left(R_{h}\right)$ or was combusted (BB) over 2002-2005. Note the difference in scale.

account with more climate variability, interannual variations in drought conditions may also be partly driving interannual variability in deforestation or fire emissions in the region (van der Werf et al., 2008). Disentangling the role of the different socio-economic, climatic, and ecological drivers represents a challenge but is necessary for future deforestation projections.

Interannual variability in deforestation and maintenance emissions were not related (Table 5), indicating that landowner decisions to burn pasture or deforest are based on different motives. This is not surprising as the two types of fire serve different purposes, and fire activity may be related to drought in a different way. Droughts lower the amount of herbaceous plant material, so fires may be prevented to save food for cattle grazing. On the other hand, droughts also facilitate the conversion process and may increase the susceptibility of fires to grow out of control. A longer study period with more climate variability is needed to further assess the relation between maintenance and deforestation fires. In our study region, the importance of maintenance fires was limited; emissions from maintenance fires were an order of magnitude smaller than emissions associated with deforestation. 


\subsection{Carbon dynamics}

The completeness of combustion and length of trajectory of conversion determines the partitioning of available biomass and litter into emissions and $R_{h}$, and also influences composition of residual biomass and litter. In general, the faster and more complete the conversion the larger the fraction of available biomass that is combusted (Morton et al., 2006). From an atmospheric $\mathrm{CO}_{2}$ perspective, the partitioning between $R_{h}$ and emissions is relatively unimportant over longer timeframes. On interannual time scales, because fires are the fastest pathway to convert biomass to atmospheric $\mathrm{CO}_{2}$ and because they are in general higher during drought years they may contribute to interannual variations in the growth rate of $\mathrm{CO}_{2}$ as a response to drought variability (Langenfelds et al., 2002). Also, the higher the combustion/respiration ratio, the more products of incomplete combustion such as $\mathrm{CO}$ and $\mathrm{CH}_{4}$ as well as aerosols and ozone precursors will be emitted, influencing climate via other, less explored pathways.

Over our relatively short study period the role of fire was 4.7 and 2.8 times as important as $R_{h}$ for conversion to cropland and pasture, respectively (Fig. 10). These results are obviously based on the assumptions of combustion completeness in our model, which are based on the combustion completeness necessary to make land suitable for cattle grazing or cropland. Especially for conversion to cropland, however, the combustion has to be complete to allow for mechanized farming methods for soybeans or other grain production (Fig. 2). Even in this region where deforestation is highly mechanized and combustion completeness is high, however, the potential release of carbon due to $R_{h}$ of soil carbon is substantial and committed emissions can almost rival fire emissions (Fig. 10). Although our results show that in these areas fire emissions may provide a reasonable proxy for carbon losses from deforestation over short timescales if emissions from non-deforestation fires (7\%) are subtracted, over longer timescales emissions could be substantially higher than those from fires only due to ongoing soil respiration (Fearnside and Barbosa, 1998). In areas with low soil carbon density, however, conversion from forest to pasture may actually increase soil carbon stocks (Holmes et al., 2006) and more detailed spatial-specific modelling is needed to fully understand the contribution of soil carbon dynamics following deforestation. We aim to include this in future DECAF versions.

\subsection{Uncertainties}

Uncertainties in emissions stem mostly from uncertainties in deforestation extent, biomass loads, and combustion completeness. Deforestation rates in the Brazilian Amazon are monitored more closely than in any other tropical forest region, and Landsat-based estimates of annual deforested area for Brazil are the best available data to characterize deforestation emissions at regional scales, although not without uncertainty. However, annual maps of deforestation are not adequate for modelling fire emissions, since the timing of forest clearing and burning may not be the same. We used active fire detections to redistribute individual clearings into years with fire activity, but this approach is limited by the detection capabilities of satellite-based fire monitoring systems.

Our modelled biomass loads compared reasonably to other estimates, especially in the Xingu basin where most deforestation takes place. We were not able to reproduce higher biomass loads in the northwest portion of the study region, and our biomass and fuel loads thus are more likely to be conservative than too high, although selective logging and understory fires may lower biomass loads prior to deforestation (Asner et al., 2005; Balch et al., 2008). Since forest degradation likely lowers the NDVI signal, the resulting decrease in biomass loads may be partly covered by our approach. Combustion completeness of the deforestation process, especially for fires following the first main fire after deforestation, remains an important area for additional field research. Our efforts to generate low, middle, and high combustion completeness scenarios provide some indication of the sensitivity of fire emissions to the efficiency of individual fire events and the overall conversion process. Since omission errors on deforestation detection may be more likely than commission errors and because DECAF estimates of biomass are near the lower range of other estimates, our emission estimates should be seen as conservative.

We aim to extend our study area to the pan-tropics to provide a new estimate of deforestation carbon fluxes, currently a highly uncertain component of the carbon cycle with estimates varying between 0.9 and $2.2 \mathrm{Pg} \mathrm{C}_{\text {year }}{ }^{-1}$ (DeFries et al., 2002; Houghton, 2003a; Achard et al., 2004). Due to more spatial variability and more plot measurements available for comparison and tuning our model, we hope to lower the uncertainty on our modelled biomass loads. In addition, the monthly time step of our model results will be suitable for use in atmospheric transport models, facilitating a comparison with atmospheric measurements providing top-down constraints on the bottom-up modelled emissions. Emissions from ongoing soil respiration can be large and are more difficult to validate than fire emissions, partly due to large spatial variability (Holmes et al., 2006), and should be an area of intense future research to allow for reliable estimates of deforestation carbon emissions. For estimates of overall net flux from deforestation over decadal time scales, carbon uptake from regrowth as well as initial fire and respiration emissions need to be included.

\section{Conclusions}

We have used remote sensing observations of deforestation extent and burned area, vegetation greenness, biogeochemical modelling, and field-based knowledge to quantify fire emissions estimates for 2001 to 2005 in the Brazilian state of 
Mato Grosso in the southern Amazon, which is undergoing rapid deforestation. Our main findings can be summarized as follows:

- For the 2001-2005 period, on average 90 (7097) $\mathrm{Tg} \mathrm{C}_{\mathrm{C}} \mathrm{yar}^{-1}$ was emitted to the atmosphere via fire. The range given was based on different assumptions of the completeness of the conversion. On average, $74 \%$ of the emissions stemmed from deforestation, the remainder from maintenance and Cerrado fires (7\%) or from conversion of Cerrado or pasture to cropland (19\%).

- Not all biomass in areas deforested was combusted in the year following deforestation; $14 \%$ of the total deforestation fire emissions occurred in the two years following deforestation. This led to a decoupling of deforestation rates and fire emissions. Also, interannual variability in deforestation and maintenance fires was not related, hinting at different motives to burn pasture or deforest. Both the distribution of combustion over multiple years and decoupling of emissions from deforestation and maintenance fires lowered interannual variability in fire emissions compared to annual deforestation rates.

- On average, $80 \%$ and $89 \%$ of the carbon in aboveground living biomass and litter was combusted when forests were converted to pasture or cropland, respectively. On annual timescales, fires may therefore provide a proxy for deforestation emissions if emissions from maintenance fires are subtracted. On longer timescales, however, emissions from soil respiration can be substantial and deforestation carbon emissions could be much higher than only those stemming from fires. Initial results showed that the increase in total deforestation emissions over longer time periods due to soil respiration could be equivalent to $54 \%$ (since $65 \%$ of aboveground and belowground carbon was combusted) and $89 \%$ (53\% of available carbon was combusted) of fire emissions for conversion to cropland and pasture respectively in the extreme case that all available carbon respires. Better constraining emissions from soil respiration, however, requires further model development and validation.

- The DECAF model has several advantages compared to previous methods to estimate fire emissions from land cover change. These include more spatial detail, a better representation of post-fire land use which influences fire processes, and the ability to partition emissions to various land use actors. These advantages are needed for setting a baseline for Reducing Emissions from Deforestation and Degradation (REDD) programs, and for the subsequent monitoring of reduction progress aimed for by these programs.
As a next step we plan to extend our study area to all tropical regions undergoing deforestation, include carbon uptake from regrowth and a better representation of the soil carbon dynamics, and include processes not included in this stage (e.g., logging) to get a better understanding of deforestation carbon dynamics on a pan-tropical scale. This will also allow for better validation of modelled biomass due to the availability of more ground truth data and a larger range of climatic conditions.

Acknowledgements. The research was supported by NASA grants NNG05GD20G, NNG04GK49G, and NNG04GD89G. GRvdW was supported by a Veni grant from the Netherlands Organization for Scientific Research.

Edited by: F. Joos

\section{References}

Achard, F., Eva, H. D., Mayaux, P., Stibig, H. J., and Belward, A.: Improved estimates of net carbon emissions from land cover change in the tropics for the 1990s, Glob. Biogeochem. Cycles, 18, doi:10.1029/2003GB002142, 2004.

Araujo, T. M., Carvalho, J. A., Higuchi, N., Brasil, A. C. P., and Mesquita, A. L. A.: A tropical rain-forest clearing experiment by biomass burning in the state of Para, Brazil, Atmos. Env., 33, 1991-1998, 1999.

Arellano, A. F., Kasibhatla, P. S., Giglio, L., van der Werf, G. R., Randerson, J. T., and Collatz, G. J.: Time-dependent inversion estimates of global biomass-burning $\mathrm{CO}$ emissions using Measurement of Pollution in the Troposphere (MOPITT) measurements, J. Geophys. Res.-Atmos., 111, D09303, doi:10.1029/2005JD006613, 2006.

Balch, J. K., Nepstad, D. C., Brando, P. M., Curran, L. M., Portela, O., de Carvalho Jr., O., and Lefebvre, P.: A negative fire feedback in a transitional forest of southeastern Amazonia, Glob. Change Biol., 14, 2276-2287, doi:10.1111/j.1365-2486.2008.01655.x, 2008.

Bishop, J. K. B. and Rossow, W. B.: Spatial and temporal variability of global surface solar irradiance, J. Geophys. Res.-Oceans, 96, 16839-16858, 1991.

Câmera, G., Valeriano D. M., Soares, J. V.: Métodologia para o Cálculo da Taxa Annual de Desmatamento na Amazônia Legal. INPE: São José dos Campos, São Paulo, Brazil. 26 pp., 2006.

Carvalho, J. A., Costa, F. S., Veras, C. A. G., Sandberg, D. V., Alvarado, E. C., Gielow, R., Serra, A. M., and Santos, J. C.: Biomass fire consumption and carbon release rates of rainforestclearing experiments conducted in northern Mato Grosso, Brazil, J. Geophys. Res.-Atmos., 106, 17877-17887, 2001.

DeFries, R. S., Houghton, R. A., Hansen, M. C., Field, C. B., Skole, D., and Townshend, J.: Carbon emissions from tropical deforestation and regrowth based on satellite observations for the 1980s and 1990s, Proc. Natl. Acad. Sci. USA, 99, 14256-14261, 2002.

DeFries, R. S., Morton, D. C., van der Werf, G. R., Giglio, L., Collatz, G. J., Randerson, J. T., Houghton, R. A., Kasibhatla, P. S., and Shimabukuro, Y.: Fire-related carbon emissions from land 
use transitions in southern Amazonia, Geophys. Res. Lett., 35, L22705, doi:10.1029/2008GL035689, 2008.

Fearnside, P. M. and Barbosa, R. I.: Soil carbon changes from conversion of forest to pasture in Brazilian Amazonia, Forest Ecol. and Manag., 108, 147-166, 1998.

Field, C. B., Randerson, J. T., and Malmstrom, C. M.: Global Net Primary Production - Combining Ecology and Remote-Sensing, Remote Sens. Environ., 51, 74-88, 1995.

Giglio, L., Descloitres, J., Justice, C. O., and Kaufman, Y. J.: An enhanced contextual fire detection algorithm for MODIS, Remote Sens. Environ., 87, 273-282, 2003.

Giglio, L., Loboda, T., Roy, D. P., Quayle, B., and Justice, C. O.: An active-fire based burned area mapping algorithm for the MODIS sensor, Remote Sens. Environ., 113, 408-420, doi:10.1016/j.rse.2008.10.006, 2009.

Grainger, A.: Difficulties in tracking the long-term global trend in tropical forest area, Proc. Natl. Acad. Sci. USA, 105, 818-823, 2008.

Guild, L. S., Kauffman, J. B., Ellingson, L. J., Cummings, D. L., and Castro, E. A.: Dynamics associated with total aboveground biomass, C, nutrient pools, and biomass burning of primary forest and pasture in Rondonia, Brazil during SCAR-B, J. Geophys. Res.-Atmos., 103, 32091-32100, 1998.

Gullison, R. E., Frumhoff, P. C., Canadell, J. G., Field, C. B., Nepstad, D. C., Hayhoe, K., Avissar, R., Curran, L. M., Friedlingstein, P., Jones, C. D., and Nobre, C.: Tropical forests and climate policy, Science, 316, 985-986, 2007.

Hansen, J., Ruedy, R., Glascoe, J., and Sato, M.: GISS analysis of surface temperature change, J. Geophys. Res.-Atmos., 104, 30997-31022, 1999.

Hansen, M. C., Townshend, J. R. G., Defries, R. S., and Carroll, M.: Estimation of tree cover using MODIS data at global, continental and regional/local scales, Int. J. Remote Sens., 26, 4359-4380, 2005.

Holmes, K. W., Chadwick, O. A., Kyriakidis, P. C., de Filho, E. P. S., Soares, J. V., and Roberts, D. A.: Large-area spatially explicit estimates of tropical soil carbon stocks and response to land-cover change, Glob. Biogeochem. Cycles, 20, GB3004, doi:10.1029/2005GB002507, 2006.

Houghton, R. A. and Hackler, J. L.: Emissions of carbon from forestry and land-use change in tropical Asia, Glob. Change Biol., 5, 481-492, 1999.

Houghton, R. A.: Revised estimates of the annual net flux of carbon to the atmosphere from changes in land use and land management 1850-2000, Tellus Series B-Chemical and Physical Meteorology, 55, 378-390, 2003a.

Houghton, R. A.: Why are estimates of the terrestrial carbon balance so different?, Glob. Change Biol., 9, 500-509, $2003 \mathrm{~b}$.

Huete A. R., Didan, K., Miura, T., Rodriguez, E. P., Gao, X., Ferreira, L. G.: Overview of the radiometric and biophysical performance of the MODIS vegetation indices, Remote Sens. Environ., 83, 195-213, 2002.

Iguchi, T., Kozu, T., Meneghini, R., Awaka, J., and Okamoto, K.: Rain-profiling algorithm for the TRMM precipitation radar, J. Applied Meteor., 39, 2038-2052, 2000.

INPE: Projecto PRODES: Monitoramento da floresta Amazonica Brasileira por satelite, Instituto Nacional de Pesquisas Espaciais, 2007.

Kauffman, J. B., Cummings, D. L., Ward, D. E., and Babbitt, R.:
Fire in the Brazilian Amazon .1. Biomass, Nutrient Pools, and Losses in Slashed Primary Forests, Oecologia, 104, 397-408, 1995.

Kauffman, J. B., Cummings, D. L., and Ward, D. E.: Fire in the Brazilian Amazon 2. Biomass, nutrient pools and losses in cattle pastures, Oecologia, 113, 415-427, 1998.

Langenfelds, R. L., Francey, R. J., Pak, B. C., Steele, L. P., Lloyd, J., Trudinger, C. M., and Allison, C. E.: Interannual growth rate variations of atmospheric $\mathrm{CO}_{2}$ and its $\delta^{13} \mathrm{C}, \mathrm{H}_{2}, \mathrm{CH}_{4}$, and $\mathrm{CO}$ between 1992 and 1999 linked to biomass burning, Glob. Biogeochem. Cycles, 16, 1048, doi:10.1029/2001GB001466, 2002.

Laurance, W. F., Albernaz, A. K. M., Fearnside, P. M., Vasconcelos, H. L., and Ferreira, L. V.: Deforestation in Amazonia, Science, 304, 1109-1109, 2004.

Litton, C. M., Raich, J. W., and Ryan, M. G.: Carbon allocation in forest ecosystems, Glob. Change Biol., 13, 2089-2109, 2007.

Los, S. O., Collatz, G. J., Sellers, P. J., Malmstrom, C. M., Pollack, N. H., DeFries, R. S., Bounoua, L., Parris, M. T., Tucker, C. J., and Dazlich, D. A.: A global 9-yr biophysical land surface dataset from NOAA AVHRR data, J. Hydromet., 1, 183-199, 2000.

Monteiro, A., Souza Jr., C., Barreto, P., Pantoja, F., and Gerwing, J.: Impactos da exploracao madeireira e do fogo em florestas de transicao da Amazonia Legal, Scientia Forestalis, 65, 11-21, 2004.

Morton, D. C., DeFries, R. S., Shimabukuro, Y. E., Anderson, L. O., Arai, E., Espirito-Santo, F. D., Freitas, R., and Morisette, J.: Cropland expansion changes deforestation dynamics in the southern Brazilian Amazon, Proc. Natl. Acad. Sci. USA, 103, 14637-14641, doi:10.1073/pnas.0606377103, 2006.

Morton, D. C., DeFries, R. S., Randerson, J. T., Giglio, L., Schroeder, W., and van der Werf, G. R.: Agricultural intensification increases deforestation fire activity in Amazonia, Glob. Change Biol., 14, 2262-2275, doi:10.1111/j.13652486.2008.01652.x, 2008.

Morton, D. C., DeFries, R. S., and Shimabukuro, Y. E.: Cropland expansion in cerrado and transition forest ecosystems: Quantifying habitat loss from satellite-based vegetation phenology, in: Cerrado land-use and conservation: assessing trade-offs between human and ecological needs, edited by: Klink, C., Conservation international, Washington D.C., in press, 2009.

Nepstad, D., Carvalho, G., Barros, A. C., Alencar, A., Capobianco, J. P., Bishop, J., Moutinho, P., Lefebvre, P., Silva, U. L., and Prins, E.: Road paving, fire regime feedbacks, and the future of Amazon forests, Forest Ecol. Manag., 154, 395-407, 2001.

New, M., Hulme, M., and Jones, P.: Representing twentieth-century space-time climate variability. Part I: Development of a 196190 mean monthly terrestrial climatology, J. Clim., 12, 829-856, 1999.

Peters, W., Jacobson, A. R., Sweeney, C., Andrews, A. E., Conway, T. J., Masarie, K., Miller, J. B., Bruhwiler, L. M. P., Petron, G., Hirsch, A. I., Worthy, D. E. J., van der Werf, G. R., Randerson, J. T., Wennberg, P. O., Krol, M. C., and Tans, P. P.: An atmospheric perspective on North American carbon dioxide exchange: CarbonTracker, Proc. Natl. Acad. Sci. USA, 104, 18925-18930, doi:10.1073/pnas.0708986104, 2007.

Potter, C. S., Randerson, J. T., Field, C. B., Matson, P. A., Vitousek, P. M., Mooney, H. A., and Klooster, S. A.: Terrestrial dcosystem production - a process model-based on global satellite and 
surface data, Glob. Biogeochem. Cycles, 7, 811-841, 1993.

Saatchi, S. S., Houghton, R. A., Alvala, R., Soares, J. V., and Yu, Y.: Distribution of aboveground live biomass in the Amazon basin, Glob. Change Biol., 13, 816-837, 2007.

Santilli, M., Moutinho, P., Schwartzman, S., Nepstad, D., Curran, L., and Nobre, C.: Tropical deforestation and the Kyoto Protocol, Clim. Change, 71, 267-276, 2005.

Seiler, W. and Crutzen, P. J.: Estimates of Gross and Net Fluxes of Carbon between the Biosphere and the Atmosphere from Biomass Burning, Clim. Change, 2, 207-247, 1980.

Shimabukuro, Y. E., Batista, G. T., Mello, E. M. K., Moreira, J. C., and Duarte, V.: Using shade fraction image segmentation to evaluate deforestation in Landsat Thematic Mapper images of the Amazon region, Int. J. Remote Sens., 19, 535-541, 1998.

Stephens, B. B., Gurney, K. R., Tans, P. P., Sweeney, C., Peters, W., Bruhwiler, L., Ciais, P., Ramonet, M., Bousquet, P., Nakazawa, T., Aoki, S., Machida, T., Inoue, G., Vinnichenko, N., Lloyd, J., Jordan, A., Heimann, M., Shibistova, O., Langenfelds, R. L., Steele, L. P., Francey, R. J., and Denning, A. S.: Weak northern and strong tropical land carbon uptake from vertical profiles of atmospheric $\mathrm{CO}_{2}$, Science, 316, 1732-1735, 2007. ter Steege, H., Pitman, N. C. A., Phillips, O. L., Chave, J., Sabatier, D., Duque, A., Molino, J. F., Prevost, M. F., Spichiger, R., Castellanos, H., von Hildebrand, P., and Vasquez, R.: Continental-scale patterns of canopy tree composition and function across Amazonia, Nature, 443, 444-447, 2006.

van der Werf, G. R., Randerson, J. T., Giglio, L., Collatz, G. J., Kasibhatla, P. S., and Arellano Jr., A. F.: Interannual variability in global biomass burning emissions from 1997 to 2004, Atmos. Chem. Phys., 6, 3423-3441, 2006, http://www.atmos-chem-phys.net/6/3423/2006/.

van der Werf, G. R., Randerson, J. T., Giglio, L., Gobron, N., and Dolman, A. J.: Climate controls on the variability of fires in the tropics and subtropics, Glob. Biogeochem. Cycles, GB3028, doi:10.1029/2007GB003122, 2008. 